\title{
Materials issues
} for quantum computation

\section{ALSO IN THIS ISSUE}

Cell and organ printing turns 15 


\section{CUSTOMIZED PRODUCTION ION IMPLANTERS}

- Beam energies from $10 \mathrm{keV}$ up to several $10 \mathrm{~s}$ of MeV

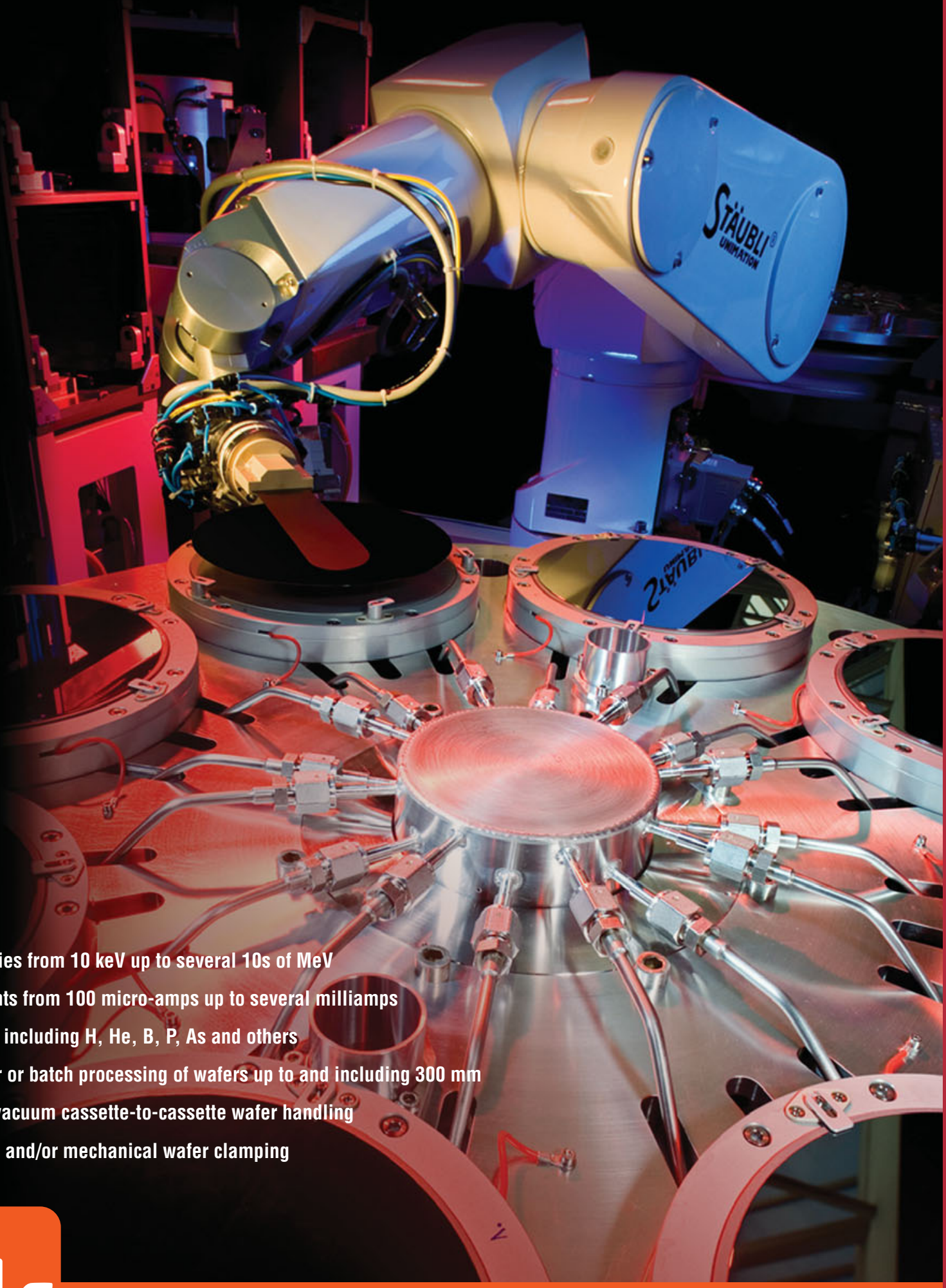

- Beam currents from 100 micro-amps up to several milliamps

- Ion species, including H, He, B, P, As and others

- Single wafer or batch processing of wafers up to and including $300 \mathrm{~mm}$

In-air or in-vacuum cassette-to-cassette wafer handling

- Electrostatic and/or mechanical wafer clamping

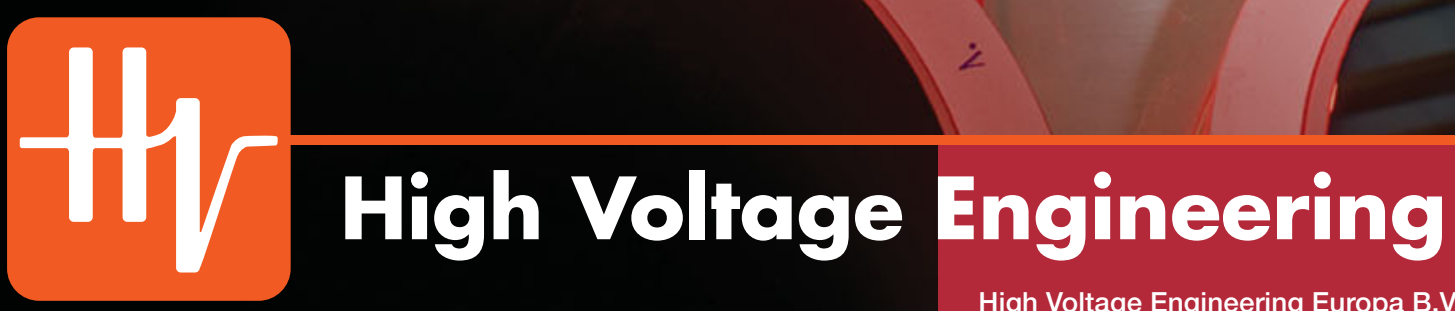

High Voltage Engineering Europa B.V.

P.O. Box 99, 3800 AB Amersfoort, The Netherlands

Tel: $31334619741 \cdot$ info@highvolteng.com

www.highvolteng.com 


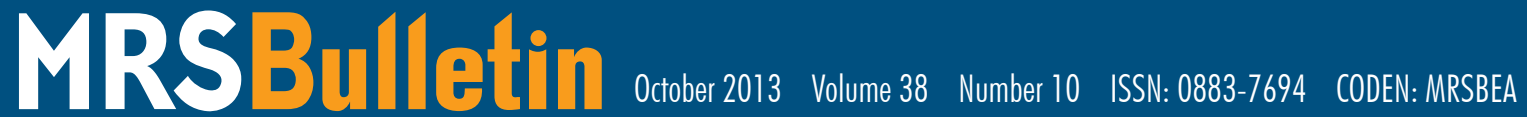
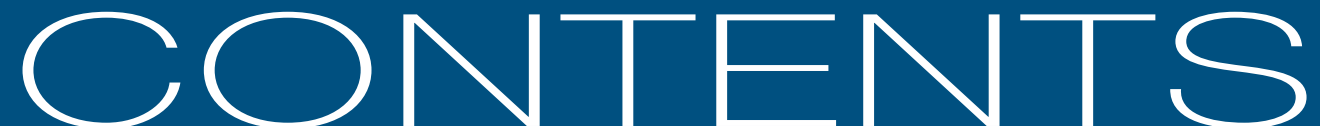

\section{MATERIALS ISSUES FOR QUANTUM COMPUTATION}

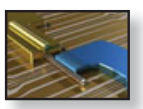

783 Materials issues for quantum computation James N. Eckstein and Jeremy Levy, Guest Editors

\section{Meet Our Authors}

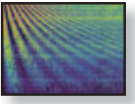

794 Semiconductor quantum dot qubits M.A. Eriksson, S.N. Coppersmith, and M.G. Lagally

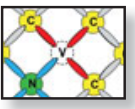

802 Quantum computing with defects Luke Gordon, Justin R. Weber, Joel B. Varley, Anderson Janotti, David D. Awschalom, and Chris G. Van de Walle

809 Quantum computing based on semiconductor nanowires Sergey M. Frolov, Sébastien R. Plissard, Stevan Nadj-Perge, Leo P. Kouwenhoven, and Erik P.A.M. Bakkers

816 Materials in superconducting quantum bits

William D. Oliver and Paul B. Welander

826 Surface science for improved ion traps D.A. Hite, Y. Colombe, A.C. Wilson, D.T.C. Allcock, D. Leibfried, D.J. Wineland, and D.P. Pappas

\section{TECHNICAL FEATURE}

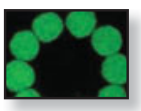

834 Cell and organ printing turns 15: Diverse research to commercial transitions Bradley R. Ringeisen, Russell K. Pirlo, Peter K. Wu, Thomas Boland, Yong Huang, Wei Sun, Qudus Hamid, and Douglas B. Chrisey

\section{DEPARTMENTS}

\section{OPINION}

766 Letter from the President

The materials research community studies magnitude of "Big Data"

Orlando Auciello

\section{NEWS \& ANALYSIS}

\section{Materials News}

- Champion nanostructures identified for solar water-splitting

- Bifunctional poly(vinylpyrrolidone) binders enhance lithium sulfide cathode performance Dominica H.C. Wong

- Shear forces self-strengthen mechanochemically active polymers Jean Njoroge

- "Chemical patchiness" guides pH-dependent assembly of nonspherical nanostructures Birgit Schwenzer

- Cu-doping enables high-efficiency flexible-substrate CdTe solar cells Colin McCormick

- Stretchable gold conductor grows its own wires

- In Memoriam: James W. Mayer Tom Picraux and Mike Nastasi

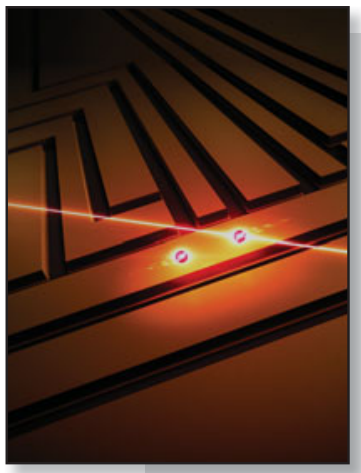

\section{ON THE COVER}

Materials issues for quantum computation. The articles in this issue of MRS Bulletin describe different approaches to quantum computing and the special materials issues affecting quantum coherence that arise in each of them. An ion trap is an example of a system that could be used for quantum computing, where the quantum state is a combination of the hyperfine electronic state of the ion and its center-of-mass motional state. The cover illustrates a specific example of an ion-trap geometry, showing a surfaceelectrode trap that employs micro-fabricated electrodes on a substrate surface. Image courtesy of Jack Bertram, Motion Forge, Inc. See the technical theme that begins on page 783. 


\section{Science Policy}

- Obama administration launches competition for three new manufacturing innovation institutes

- Open access to research publications reaching "tipping point"

- NSF releases study on regional concentration of scientists and engineers

\section{Public Affairs Forum}

- Unlocking materials opportunities in manufacturing Andrew Steigerwald

\section{FEATURES}

780 Beyond the Lab

Navy SeaPerch competition spreads STEM awareness Steven Spurgeon

864 Image Gallery Look Again

\section{SOCIETY NEWS}

- Preview: 2013 Materials Research Society Fall Meeting \& Exhibit

- Mildred S. Dresselhaus to receive 2013 Von Hippel Award for carbon science

- Robert 0. Ritchie selected for 2013 David Turnbull Lectureship

- Alexander A. Balandin named 2013 MRS Medalist for graphene thermal properties

- David J. Srolovitz receives 2013 Materials Theory Award

- David L. Morse to give plenary address on glass at 2013 MRS Fall Meeting

\section{CAREER CENTRAL}

\section{ADVERTISERS IN THIS ISSUE}

American Elements

American Scientific Publishers

Asylum Research

an Oxford Instruments Company

High Voltage Engineering

Hindawi Publishing Corporation

JEOL USA, Inc.

The Kavli Foundation

Kurt J. Lesker Company

MMR Technologies, Inc.

National Electrostatics Corp.

Park Systems, Inc.

Strem Chemicals, Inc.
Page No.

.771

782

Inside front cover Inside back cover 


\section{About the Materials Research Society}

The Materials Research Society (MRS), a not-for-profit scientific association founded in 1973 and headquartered in Warrendale, Pennsylvania, USA, promotes interdisciplinary materials research. Today, MRS is a growing, vibrant, member-driven organization of over 16,000 materials researchers spanning over 80 countries, from academia, industry, and government, and a recognized leader in the advancement of interdisciplinary materials research.

The Society's interdisciplinary approach differs from that of single-discipline professional societies because it promotes information exchange across many scientific and technical fields touching materials development. MRS conducts three major international annual meetings encompassing approximately 125 topical symposia, and also sponsors numerous single-topic scientific meetings. The Society recognizes professional and technical excellence and fosters technical interaction through University Chapters. In the international arena, MRS implements bilateral projects with partner organizations to benefit the worldwide materials community. The MRS Foundation helps the Society advance its mission by supporting various projects and initiatives.

MRS publishes MRS Bulletin, MRS Communications, the MRS Online Proceedings Library, Journal of Materials Research, MRS Energy \& Sustainability, and books and textbooks with its publishing partner, Cambridge University Press.

2013 MRS BOARD OF DIRECTORS

President Orlando Auciello, University of Texas at Dallas, USA

Immediate Past President Bruce M. Clemens, Stanford University, USA

Vice President and President-Elect Tia Benson Tolle, The Boeing

Company, USA

Secretary Sean J. Hearne, Sandia National Laboratories, USA

Treasurer Michael R. Fitzsimmons, Los Alamos National Laboratory, USA

Executive Director Todd M. Osman, Materials Research Society, USA

Ana Claudia Arias, University of California-Berkeley, USA

Shenda Baker, Synedgen, Inc/Harvey Mudd College, USA

David Cahen, Weizmann Institute of Science, Israel

Duane B. Dimos, Sandia National Laboratories, USA

Steve Eglash, Stanford University, USA

Chang-Beom Eom, University of Wisconsin-Madison, USA

Susan Ermer, Lockheed Martin Advanced Technology Center, USA

Eric Garfunkel, Rutgers University, USA

Sossina M. Haile, California Institute of Technology, USA

Andrea M. Hodge, University of Southern California, USA

Oliver Kraft, Karlsruhe Institute of Technology, Germany

Hideki Matsumura, Japan Advanced Institute of Science and Technology, Japan

Fiona C. Meldrum, University of Leeds, UK

Eric A. Stach, Brookhaven National Laboratory, USA

Stephen Streiffer, Argonne National Laboratory, USA

Susan E. Trolier-McKinstry, The Pennsylvania State University, USA

\section{MRS OPERATING COMMITTEE CHAIRS}

Academic Affairs M. Stanley Whittingham, SUNY-Binghamton, USA

Awards C. Barry Carter, University of Connecticut, USA

Government Affairs Nabil Bassim, US Naval Research Laboratory, USA

Meetings Committee David S. Ginley, National Renewable Energy

Laboratory, USA

Member Engagement Yves Chabal, The University of Texas at Dallas, USA Public Outreach Aditi Risbud, University of Utah in Salt Lake City, USA

Publications Paul McIntyre, Stanford University, USA

MRS OFFICE OF PUBLIC AFFAIRS

Ron Kelley 499 South Capitol St. SW, Suite 600, Washington, DC 20003
EDITORIAL OFFICE 506 Keystone Drive, Warrendale, PA 15086-7573 USA

Bulletin@mrs.org tel 724.779 .2747 fax 724.779.8313 www.mrs.org
Editor

Gopal R. Rao, rao@mrs.org

Managing Editor

Judy Meiksin, meiksin@mrs.org

Technical Editor

Lori A. Wilson, Iwilson@mrs.org

Editorial Assistants

Ben Moriarty, moriarty@mrs.org

Mary Wilmoth

Associate Technical Editor

Aniketa Shinde

Production/Design

Andrea Pekelnicky, Rebecca Yokum,

and TNQ

Production Editor

Catherine Paduani

Science News Editor

Tim Palucka

Principal Development Editor

Elizabeth L. Fleischer

Director of Communications

Eileen Kiley Novak
Guest Editors

James N. Eckstein and Jeremy Levy

\section{Energy Quarterly}

David Cahen (Chair),

Anshu Bharadwaj, Russell R. Chianelli, George Crabtree, Sabrina Sartori,

Anke Weidenkaff,

M. Stanley Whittingham,

and Steve M. Yalisove

\section{Advertising/Sponsorship}

Mary E. Kaufold, kaufold@mrs.org

Donna L. Watterson, watterson@mrs.org

Member Subscriptions

Michelle Judt, judt@mrs.org

Non-Member Subscriptions

subscriptions_newyork@cambridge.org

\section{EDITORIAL BOARD}

Paul S. Drzaic (Chair), Apple, Inc., USA

V.S. Arunachalam, Center for Study of Science, Technology \& Policy, India

Marie-Isabelle Baraton, University of Limoges, France

Hanns-Ulrich Habermeier, Max Planck Institute for Solid State Research, Germany

Igor Lubomirsky, Weizmann Institute, Israel

Fiona C. Meldrum, University of Leeds, UK

Amit Misra, Los Alamos National Laboratory, USA

Steven C. Moss, Aerospace Corporation, USA

Julie A. Nucci, Cornell University, USA

Linda J. Olafsen, Baylor University, USA

James W. Stasiak, Hewliett-Packard Co., USA

Carol Trager-Cowan, University of Strathclyde, UK

Eric Werwa, Washington, DC, USA

Steve M. Yalisove, University of Michigan, USA

\section{VOLUME ORGANIZERS}

2014 Deborah E. Leckband, University of Illinois at Urbana-Champaign, USA Yuri Suzuki, Stanford University, USA

Enrico Traversa, King Abdullah University of Science and Technology, Saudi Arabia Yonhua Tzeng, National Cheng Kung University, Taiwan

2013 Mark T. Lusk, Colorado School of Mines, USA Eva Olsson, Chalmers University of Technology, Sweden Birgit Schwenzer, Pacific Northwest National Laboratory, USA James W. Stasiak, Hewlett-Packard Co., USA

2012 Lei Jiang, Chinese Academy of Sciences, China Sergei V. Kalinin, Oak Ridge National Laboratory, USA Stéphanie P. Lacour, EPFL, Switzerland Steven C. Moss, Aerospace Corporation, USA

MRS Bulletin (ISSN: 0883-7694, print; ISSN 1938-1425, online) is published monthly by the Materials Research Society, 506 Keystone Drive, Warrendale, PA 15086-7573. Copyright @ 2013 Materials Research Society. Permission required to reproduce content. Periodical postage paid at New York, NY, and at additional mailing offices. POSTMASTER: Send address changes to MRS Bulletin in care of the Journals Department, Cambridge University Press, 100 Brook Hill Drive, West Nyack, NY 10994-2113, USA. Printed in the U.S.A.

Membership in MRS is $\$ 115$ annually for regular members, $\$ 30$ for students. Dues include an allocation of $\$ 29$ (\$17 for students) to a subscription to MRS Bulletin. Individual member subscriptions are for personal use only. Non-member subscription rates are $\$ 394$ for one calendar year (12 issues) within North America and $\$ 479$ elsewhere. Requests from subscribers for missing journal issues will be honored without charge only if received within six months of the issue's actual date of publication.

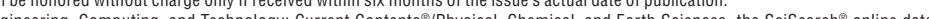
bese, Research Alert ${ }^{\oplus}$ Science Citation Index ${ }^{\circledast}$, and the Materials Science Citation IndexTM. Back volumes of MRS Bulletin are available on microfiche through University Microfilms Inc. 300 North Zeeb Road, Ann Arbor, MI 48106, USA.
Send Letters to the Editor to Bulletin@mrs.org. Include your name, affiliation, and full contact information. 
The Norwegian Academy of Science and Letters announces the

\section{CALL FOR NOM I N ATIONS 2014

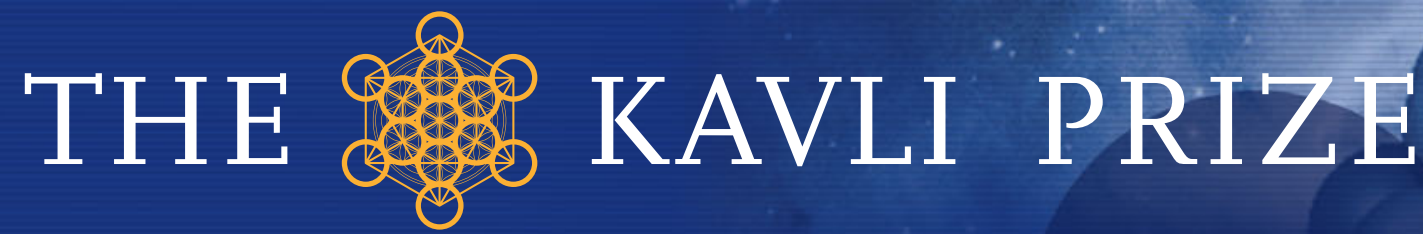

For outstanding scientific research in

\section{ASTROPHYSICS • NANOSCIENCE • N NEUROSCIENCE}

Nomination deadline: December 1, 2013

Nominations will be reviewed by committees of leading international scientists appointed by

The Norwegian Academy of Science and Letters based on recommendations by

The Chinese Academy of Sciences The French Academy of Sciences The Max Planck Society (Germany) The National Academy of Sciences (US)

The Royal Society (UK)

The Kavli Prize will be awarded in Oslo in September 2014 and will consist of

A gold medal - US $\$ 1,000,000$. A scroll

For details about the nomination process see

www.kavliprize.no

A partnership of

然

THE NORWEGIAN MINISTRY OF EDUCATION AND RESEARCH
THE 鹫 KAVLI FOUNDATION 